\title{
PENGGUNAAN FLASHCARD UNTUK KEMAMPUAN MEMBACA ANAK 5 TAHUN DENGAN METODE BERCERITA
}

\author{
Indaria Tri Hariyani ${ }^{1}$, Febry Hidayatul Umamia ${ }^{2}$, Norma Diana Fitri ${ }^{3}$ \\ PG-PAUD, STKIP BIM, Jl. Raya Benowo No.1-3, Surabaya, 60197 \\ Penulis untuk korespondensi/ E-mail: indariatrihariani@stkipbim.ac.id
}

\begin{abstract}
Abstrak - Salah satu komponen perkembangan bahasa adalah kemampuan membaca dan mengenal huruf-huruf abjad dari A sampai Z. Kemampuan membaca anak memerlukan stimulus yang tepat agar dapat mengembangkan kemampuan membaca sesuai dengan usianya.Media flashcard merupakan salah satu media untuk mengembangkan kemampuan membaca. Adapun tujuan penelitian ini adalah untuk menggambarkan penggunaan flashcard untuk kemampuan membaca anak usia 4-5 tahun. Pendekatan penelitian yang digunakan dalam penelitian ini adalah metode kualitatif, subjek dalam penelitian ini adalah guru, siswa dan walimurid TK A dengan jumlah 1 guru TK A, 5 siswa TK A, dan 1 Wali murid di TK Az-Zahra Klumprik Surabaya, jadi seluruh subjek ada 7 orang. Teknik penentuan subjek pada penelitian ini adalah purposive sampling.Teknik pengumpulan data menggunakan observasi, wawancara, dan dokumentasi, sementara untuk validasi data digunakan teknik triangulasi. Hasil penelitian mengungkapkan bahwa penggunaan media flashcard mampu mengembangkan kemampuan membaca anak melalui metode bercerita dengan bantuan gambar dan huruf dari alfabet A-Z. Media flashcard dapat membuat anak tertarik, mudah mengingat kosakata baru, mampu menyebutkan bentuk dan bunyi huruf, melatih keterampilan mendengarkan, dan merangsang anak untuk berpikir serta kemudian membuat anak dapat mengeluarkan imajinasinya.Jadi kesimpulannya penggunaan media flashcard mampu mengembangkan kemampuan membaca anak usia 5 tahun di TK Az-Zahra Klumprik Surabayadengan metode bercerita,
\end{abstract}

\section{Kata Kunci: Kemampuan Membaca, Flashcard, Anak 5 Tahun}

Abstract - One component of language development is the ability to read and recognize the letters of the alphabet from A to Z. Children's reading ability requires the right stimulus in order to develop reading skills according to their age. Flashcard media is one of the media to develop reading skills. The purpose of this study was to describe the use of flashcards for the reading ability of children aged 4-5 years. The research approach used in this study is a qualitative method, the subjects in this study were teachers, students and guardians of Kindergarten A with 1 teacher in Kindergarten A, 5 students in Kindergarten A, and 1 Guardian in Kindergarten Az-Zahra Klumprik Surabaya, so all subjects there are 7 people. The technique of determining the subject in this study was purposive sampling. Data collection techniques used observation, interviews, and documentation, while for data validation triangulation techniques were used. The results of the study revealed that the use of flashcard media was able to develop children's reading skills through the storytelling method with the help of pictures and letters from the A-Z alphabet. Flashcard media can make children interested, easy to remember new vocabulary, able to mention the shape and sound of letters, practice listening skills, and stimulate children to think and then make children able to express their imagination. So in conclusion, the use of flashcard media is able to develop the reading skills of children aged 5 years in TK Az-Zahra Klumprik Surabaya with the storytelling method.

Keywords: Reading Ability, Flashcard, Child Aged 5 Years 


\section{PENDAHULUAN}

$\mathrm{P}$ endidikan anak usia dini mulai memperoleh perhatian banyak orang, terutama setelah disadari bahwa pendidikan pada masa-masa ini sangat mempengaruhi tahap berikutnya. Pendidikan yang dilakukan pada usia dini hakikatnya adalah upaya memfasilitasi perkembangan yang sedang dialami oleh anak usia 0-6 tahun (Bachtiar, 2005). Anak usia dini adalah masa usia emas bagi pertumbuhan dan perkembangannya. Menurut Dryden \& Vos (2001), perkembangan bahasa mempunyai peranan yang sangat penting, karena berkaitan dengan otak kanan. Sampai usia 4 tahun otak manusia berfungsi $50 \%$, sampai usia 8 tahun otak manusia berfungsi $80 \%$, sehingga sejak usia 8 tahun kecerdasan manusia hanya bertambah $20 \%$. Dengan demikian perlu perhatian yang lebih serius pada anak usia dini di lembaga pendidikan anak usia dini formal maupun non formal.

Seorang anak dengan usia antara 3-6 tahun dianggap dalam anak usia dini. Anak usia dini, di sisi lain, ialah pribadi yang unik dengan pola perkembangan dan pertumbuhan fisik, kognitif, sosio-emosional, kreatif, bahasa, serta karakteristik komunikasi khusus yang tergantung pada tahap perkembangan anak (Augusta, 2012). Hingga kini pendidikan anak usia dini masih memprihatinkan. Hal ini dapat dilihat dari sisi akses masih rendah, begitu pula sisi kualitas masih jauh dari harapan, bahkan banyak PAUD yang melakukan keliruan baik pengelolaan maupun sistem pembelajarannya. Adapun bentuk missconception yang paling menonjol adalah pemaksaan pengajaran bacatulis-hitung. Hal semacam ini yang sering menjadi sorotan (Siti, 2010). Padahal masa anak usia dini adalah fase bermain, dalam istilah Jean Piaget berada pada tahap preoperasional, maka salah jika memaksakan kegiatan belajar yang bertolak belakang dengan dunianya, (Anam, 2007). Maka para ahli sependapat bahwa sistem pendidikan yang sesuai dengan perkembangan anak usia dini adalah bermain sambil belajar.

Berdasarkan disiplin ilmu Psikologi perkembangan masa anak usia dini merupakan masa yang terpenting dalam perkembangan kognitif, fisik, sosial, bahasa, emosi, juga moral anak. Pada masa ini, pendidikan harus di fokuskan pada permainan dan kasih sayang. Pembelajaran anak usia dini adalah bermain sambil belajar. Hal tersebut merupakan suatu tantangan tersendiri bagi guru. Dengan melihat kenyataan tersebut sebagai seorang guru perlu berfikir kreatif dan inovatif untuk mencari cara memudahkan anak dalam pengembangan kemampuan dasar bahasanya.

Salah satu aspek yang perlu dikembangkan sejak dini adalah bahasa. Menurut Anonim (2008), anak usia dini merupakan masa emas atau paling ideal untuk belajar bahasa selain bahasa ibu (bahasa pertama). Daya pikir (otak) anak lebih lentur. Makanya, ia lebih mudah belajar bahasa. Sedangkan sesudahnya akan makin berkurang dan pencapaiannya pun tidak maksimal. Menurut Effendy dalam Sugiarsih (2021), bahasa dipandang sebagai alat yang paling sempurna yang dapat dimanfaatkan untuk mengungkapkan pikiran dan perasaan positif dalam bentuk nyata atau abstrak. Bahasa terdiri dari 4 macam bentuk yaitu menyimak, berbicara, membaca dan menulis (Bromley dalam Djamarah, 2011). Kemampuan bahasa merupakan salah satu kemampuan dasar yang harus dimiliki anak, yang terdiri dari beberapa tahap sesuai dengan karakteristik dan perkembangannya. Kemampuan berbahasa tersebut meliputi kemampuan berbicara, menyimak, membaca dan menulis (Dhieni, 2011). Perkembangan bahasa anak dipengaruhi oleh beberapa faktor termasuk usia anak, kondisi lingkungan, kecerdasan anak, status sosial ekonomi dan kondisi fisik anak tersebut (Sunarto dan Hartono, 2013). Pada masa kanakkanak inilah, anak mulai mengkombinasikan suku kata menjadi kata, dan kata menjadi kalimat.

Rendahnya kemampuan bahasa anak usia dini di TK Az-Zahra Klumprik Surabaya, ditunjukan dengan kemampuan anak dalam mengemukakan ide atau gagasan masih rendah, seperti pada kegiatan menceritakan gambar yang disediakan. Pada saat anak diminta menceritakan gambar yang disediakan, anak hanya menjawab satu nama dalam gambar sementara dalam gambar terdapat bermacam-macam gambar. Bahkan ada beberapa anak menjawab "tidak tahu", tidak mau atau menggeleng kepala. Ini disebabkan karena latar belakang keluarga yang kurang mendukung pembelajaran bahasa, pendekatan 
pembelajaran yang kurang menarik, pemilihan bahan ajar bahasa yang kurang tepat disekolah, komunikasi yang kurang hangat antara guru dengan siswa, serta penyampaiannya yang kurang variatif dalam pembelajaran bahasa pada anak usia dini.

Kondisi seperti ini tentu saja tidak dapat dibiarkan. Kemampuan membaca anak tidak dapat berkembang dengan baik sesuai tahapan perkembangan bahasa. Hal ini akan berpengaruh pada perkembangan bahasa anak selanjutnya. Untuk mengatasi permasalahan tersebut, guru menggunakan media flashcard untuk kemampuan membaca anak 5 tahun dengan metode bercerita.

Flashcard adalah kartu belajar yang efektif dan efesien untuk mengingat dan menghafal $3 \mathrm{x}$ lebih cepat. Dapat dilihat dari penelitian Wati bahwa media pembelajaran flashcard dapat menarik minat dan menambah daya ingat siswa dalam berlangsungnya pembelajaran Al Qur'an Hadits sehingga ilmu yang diajarkan bisa diserap dengan baik. Kartu ini mempunyai dua sisi, sisi depan dan sisi belakang. Sisi depan tertulis judul bab, istilah, gambar, pertanyaan atau pernyataan yang perlu diingat. Sementara sisi belakang tertera mind map, definisi, keterangan gambar, jawaban, atau uraian (Makrifah, 2014). Namun, tidak semua kartu dalam flashcard seperti di atas, karena flashcard pada dasarnya adalah kartu bergambar yang membantu anak belajar mengingat dan menghafal. Karena tujuan dari metode ini adalah melatih kemampuan otak kanan untuk mengingat gambar dan kata-kata, sehingga 5 perbendaharaan kata dan kemampuan membaca anak bisa dilatih dan ditingkatkan sejak usia dini. Hal ini merupakan satu tantangan tersendiri bagi guru. Guru perlu berfikir kreatif dan inovatif untuk mencari cara memudahkan anak dalam pengembangan kemampuan dasar bahasanaya.

Adapun identifikasi masalah diturunkan berdasarkan latar belakang yang disebutkan di atas yakni pemahaman anak tentang mengenal huruf masih kurang, sebagian besar mengalami kesulitan dalam memahami suatu huruf, kurangnya sebuah benda untuk mengenalkan huruf pada anak. Identifikasi Masalah masih terlalu luas berdasarkan masalah yang disebutkan, sehingga harus dipersempit. Dalam penelitian ini, masalah dibatasi pada pemanfaatan Media Flashcard oleh guru di TK Az-Zahra Klumprik Surabaya dan penerapannya untuk kemampuan membaca. Sehingga yang menjadi rumusan masalah dalam penelitian ini adalah: bagaimana penggunaan media Flashcard untuk kemampuan membaca anak usia 5 tahun dengan metode bercerita di TK AzZahra Klumprik Surabaya?.

\section{METODE PENELITIAN}

\section{Jenis Penelitian}

Penelitian ini menggunakan jenis penelitian kualitatif dengan metode penelitiannya adalah deskriptif kualitatif. Alasan peneliti menggunakan metode penelitian kualiatif yaitu karena hasil data yang diteliti tidak berupa angka melainkan uraian deskriptif.

Tujuan peneliti yaitu untuk mendeskripsikan penggunaan media Flashcard untuk kemampuan membaca anak usia 5 tahun dengan metode bercerita di TK Az-Zahra Klumprik Surabaya. Dengan menggunakan metode ini maka akan dapat diamati bagaimana keadaan yang sedang berlangsung saat ini (Sugiyono, 2017).

\section{Tempat dan Waktu Penelitian}

Penelitian dilaksanakan di TK Az-Zahra yang terletak di Klumprik, Wiyung Surabaya. pelaksanaan penelitian pada kurun waktu 1 bulan tahun 2021 .

\section{Subjek dan Objek Penelitian}

Subjek dalam penelitian ini adalah guru, siswa dan wali murid TK A dengan jumlah 1 guru TK A, 5 siswa TK A, dan 1 Wali murid di TK AzZahra Klumprik Surabaya. Jadi seluruh subjek ada 7 orang. Teknik pengambilan subjek pada penelitian ini adalah purposive sampling. Purpossive sampling adalah teknik pengambilan sampel sumber data dengan pertimbangan tertentu (Sugiyono, 2017). Objek penelitian yang dikaji dalam penelitian ini adalah kemampuan membaca anak.

\section{Teknik dan Instrumen Pengumpulan Data}

Pengumpulan data adalah langkah yang paling berperan penting dalam berjalannya 
suatu penelitian. Teknik pengumpulan data menurut Sugiyono (2017) merupakan langkah yang paling strategis dalam penelitian, karena tujuan utama dari penelitian adalah mendapatkan data.Pada penelitian ini teknik pengumpulan data yang digunakan yaitu observasi, wawancaradan dokumentasi.

Data dalam penelitian ini berupa data yang didapat dari vidio call dengan murid, saat observasi bersama anak-anak dalam waktu 5 hari pada tanggal 14 Juni - 18 Juni 2021. Data setiap vidio call dibagi menjadi beberapa foto untuk dianalisis sebagai data dokumentasi. Untuk data wawancara didapat dengan melakukan tanya jawab secara langsung kepada guru kelas dan salah satu dari wali murid.

\section{Keabsahan Data}

Untuk mendapatkan data yang valid, maka penelitian ini perlu dilakukan uji keabsahan data. Triangulasi adalah teknik pemeriksaan keabsahan data yang memanfaatkan sesuatu yang lain. Menurut Sugiyono (2017), terdapat tiga macam triangulasi yaitu: triangulasi teknik, triangulasi sumber, dan triangulasi waktu. Pada penelitian ini menggunakan keabsahan data dengan triangulasi teknik dan sumber.

\section{Teknik Analisis Data}

Penelitian ini menggunakan model analisis dari Miles dan Huberman. Komponen-komponen analisis data menurut Sugiyono (2017) sebagai berikut: data collection ( pengumpulan data), data reduction (reduksi data), data display (penyajian data), dan coclusion drawing/ verification.

\section{HASIL DAN PEMBAHASAN}

Hasil penelitian mengungkapkan bahwa penggunaan media flashcard mampu mengembangkan kemampuan membaca anak melalui metode bercerita dengan bantuan gambar dan huruf dari alfabet A-Z pada media flashcard dapat membuat anak tertarik, mudah mengingat kosakata baru, mampu menyebutkan bentuk dan bunyi huruf, melatih keterampilan mendengarkan, dan merangsang anak untuk berpikir serta kemudian membuat anak dapat mengeluarkan imajinasinya.
Hal ini menjelaskan bahwa media pembelajaran sangat penting dalam kualitas pembelajaran. Pendidik harus mampu mengembangkan dan mengatur secara menarik agar pembelajaran menjadi menyenangkan dan dapat dipahami.

Berikut tata cara pelaksanaan kegiatan mengembangkan kemampuan membaca dengan memanfaatkan media flashcard yaitu seperti:

1 Guru menyiapkan kain flanel sesuai dengan huruf adjad dan inisial gambar. Misalnya guru meneyebutkan huruf dan gambargamabar tersebut.

2 Guru menggunakan flashcard, kemudian mengajak anak membaca huruf abjad, selain itu juga anak disuruh menyebutkan sebuah gambar yang dibawah huruf, lalu guru bercerita memanfaat dan kegunaan gambar tersebut, dan di akhir abjad anak disuruh melengkapi huruf adjad yang hilang.

3 Guru mendorong siswa untuk cepat mengingat huruf-huruf alfabet dan tidak bosan ketika diajarkan membaca, dan siswa yang paling berani didorong untuk mendorong teman-temannya.

4 Guru mengajukan pertanyaan tentang topik cerita.

5 Guru mengajak siswa untuk menceritakan kembali narasi yang baru didengarnya.

6 Dua atau tiga anak dipilih oleh guru untuk maju dan mengulangi narasi yang baru saja dipresentasikan di depan kelas. Anak yang paling berani pergi ke anak yang dipilih, sedangkan yang paling pemalu pergi ke anak yang dipilih.

7 Setelah itu, dengan memanfaatkan media flashcard flanel, pengajar dapat memberikan kesempatan kepada siswa untuk menceritakan cerita berdasarkan imajinasi atau pengalaman pribadi mereka. Instruktur hanya memandu; jika diperlukan, guru berpartisipasi untuk mengarahkan cerita.

Anak-anak membutuhkan perantara, seperti media, untuk membantu mereka memahami informasi yang diberikan oleh instruktur, yang kemudian dapat diterima atau dipahami oleh siswa. Media flashcard yang digunakan dapat mengubah barang-barang yang sulit dijangkau menjadi sesuatu yang nyata bagi anak-anak melalui model imitasi. Akibatnya, anak berusia 
5-6 tahun dapat fokus pada penyampaian narasi dasar yang sesuai dengan kepribadiannya. Dia akan mendengarkan narasi dan menghargainya, setelah itu dia akan menceritakan kembali cerita itu dalam bahasanya sendiri.

Adapun secara terperinci temuan penelitian di lapangan sebagaimana berikut ini:

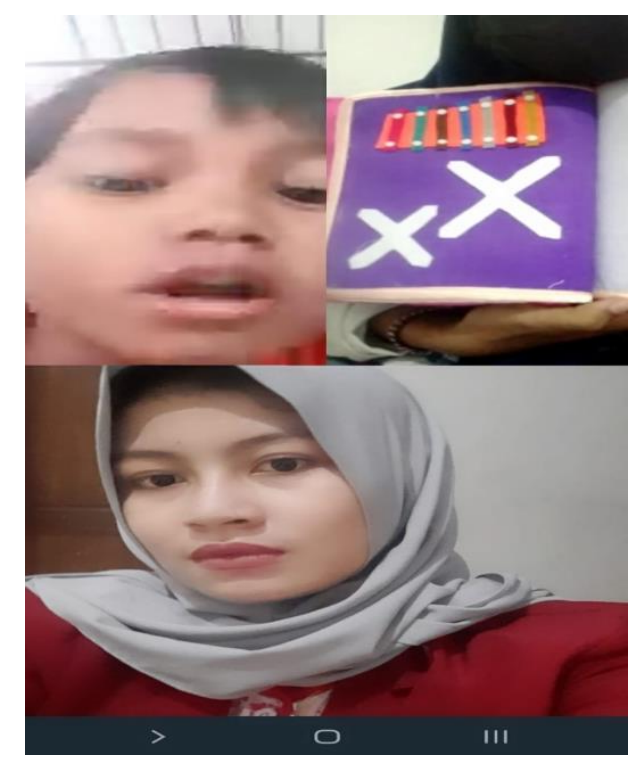

Gambar 1. Kegiatan proses penggunaan flashcard

\section{Penggunaan media flashcard untuk kemampuan membaca anak usia 5 tahun dengan metode bercerita di TK Az-Zahra Klumprik Surabaya}

Didasarkan pada hari pertama observasi tanggal 17 Juni 2021 tentang penggunaan media flashcard untuk kemampuan membaca anak usia 5 tahun dengan metode bercerita di Tk Az-Zahra Klumprik Surabaya dimana peneliti melihat bahwa si A.A mengetahui huruf A-Z dengan benar maksimal tanpa bantuan oleh guru maka dari itu si A.A sudah berkembang sesui dengan harapan [CO P1 B3-B5]. Dibuktikan juga dengan pernyataan $\mathrm{Bu} \mathrm{D}$ bahwa "anak-anak Alhamdulilah, jadi tertarik mengenal huruf dengan menggunakan media flashcard tersebut. Terbukti bahwa A.A bisa mengetahui huruf dari A sampai $Z$ ' [CW $01 \mathrm{P} 3]$.

Faktor pendukung penggunaan media flashcard untuk kemampuan membaca anak usia 5 tahun dengan metode bercerita di TK Az-Zahra Klumprik Surabaya
Berdasarkan dari hasil observasi, wawancara dan dokumentasi dalam faktor pendukung penggunaan media flash di TK Az-Zahra Klumprik Surabaya peneliti menemukan anak berkembang sangat baik dan berkembang sesuai harapan disaat guru kelas memberikan pelajaran dengan menggunakan media flashcard tersebut. Hal tersebut dapat dibuktikan pada catatan wawancara peneliti pada tanggal 18 Juni 2021 "dengan adanya media flashcard huruf yang peneliti berikan ini sangat membantu guru dan siswa bukan hanya belajar mengenal huruf saja, tetapi bisa belajar sambil bercerita dan mengenalkan berbagai macam gambar, warnawarna juga yang ada didalam media flashcard tersebut". [CW $01 \mathrm{P} 4]$.

Anak-anak usia 5 tahun di TK Az-Zahra keinginan mengenal huruf abjad $\mathrm{A}-\mathrm{Z}$ saat ini sangat semangat dengan adanya media flashcard, anak-anak tidak hanya mengenal huruf A-Z saja tetapi anak-anak senang bisa mengetahui berbagai macam gambar-gambar, warna-warnai yang ada didalam media. Jadi anak-anak sangat tertarik dan tidak mudah bosan disaat pembelajaran secara langsung.

Peneliti juga bertanya kepada $\mathrm{Bu} \mathrm{D}$ tentang faktor pendukung dalam menggunakan media flashcard terhadap kemampuan membaca anak. $\mathrm{Bu} \mathrm{D}$ menjawab: "Faktor yang mendukung pembelajaran mengenal huruf abjad A-Z bisa diperoleh guru menggunakan media flashcard bisa dipahami dengan mudah, menarik perhatian anak-anak usia 5 tahun dan juga lebih mudah diingat anak-anak saat belajar membaca." [CW 01 P5].

Dari hasil wawancara, peneliti dengan guru kelas yang bernama $\mathrm{Bu} \mathrm{D}$ menyatakan faktor pendukung adanya pengunaan media flashcard anak usia 5 tahun di Tk Az-Zahra Klumprik Surabaya yaitu, "adanya peningkatan kepada anak didiknya semuanya yang berawal dari anak yang kurang semangat dengan membaca dan mengenal huruf anak-anak jadi tertarik dengan pembelajaran menggunakan media flashcard tersebut (CW 01 P5). Dan adanya media flashcard tersebut pendidik lebih mudah berkomunikasi dengan anak-anak, tetapi pendidik bisa belajar sambil bercerita dan mengenalkan berbagai macam-macam gambar, warna-warna yang ada didalam media tersebut." (CW $01 \mathrm{P} 4)$. 
Peneliti melakukan wawancara dengan salah satu wali murid TkAz-Zahra Klumprik Surabaya dengan adanya penggunaan media flashcard di TK Az-Zahra bahwa wali murid mengatakan "anaknya mempunyai semangat tinggi untuk belajar mengenal huruf abjad yang berawal kurang tertarik menjadi semangat sekali disaat pembelajaran menggunakan media flashcard tersebut." (CW 02 P2).

Faktor penghambat penggunaan media flashcard untuk kemampuan membaca anak usia 5 tahun dengan metode bercerita di TK Az-Zahra Klumprik Surabaya

Pada saat penelitian dilakukan ternyata juga ada faktor penghambat dalam penggunaan media flashcard anakusia 5 tahun di TK Az-Zahra Klumprik Surabaya. Menurut hasil dari observasi di TK Az-Zahra Klumprik Surabaya, penghambatnya yaitu adanya salah satu dari siswa yang masih bingung membedakan anatara huruf $B$ dan $D$ karena kurang fokus terhadap penyampaian yang diberikan oleh guru. [CO P6 B2]. Ditemukan pula adanya anak yang masih belum berkembang sesuai harapan (BSH) tetapi sudah mulai mengetahui sedikit demi sedikit huruf A-Z sehingga penilaiannya masuk dalam kategori mulai berkembang (MB). Penilaian tersebut juga merupakan capaian kemajuan yang diraih anak dimana anak sebelumnya masih terlihat bingung dan sama sekali belum mengetahui mengenai huruf.

Dari hasil wawancara, observasi, dan dokumentasi pada guru kelas dan wali murid, peneliti juga menemukan faktor penghambat dalam penggunaan media flashcard anak usia 5 tahun di TK Az-Zahra Klumprik Surabaya yaitu: terbatasnya waktu untuk menyampaikan materi kepada anak, jika terlalu lama waktu yang diberikan anak merasa kurang konsentrasi dan bosan, terhalang oleh sinyal terkadang kurang maksimal dalam menyampaikan materi juga menerima materi yang didaptkan anak Apalagi sekolah saat ini dengan cara daring tidak secara tatap muka. Hal ini dibuktikan dari hasil wawancara pada tanggal 18 Juni 2021 bu D menjawab: "Pada saat menerapkan pembelajaran membutuhkan waktu yang sangat banyak apalagi sekarang pembelajaran dilaksanakan secara daring dan tidak bisa tatap muka sama sekali tentunya melebihi waktu yang sudah ditentukan apalagai mengembangkan dengan media flashcard masih dalam tahap awal, jadi membutuhkan waktu dan rencana pembelajaran yang lama". (CW $01 \mathrm{P} 6)$.

Hal ini terbukti dari wawancara dilakukan dengan salah satu wali murid TK Az-Zahra Klumprik Surabaya yaitu sebagai orang tua yang tidak memiliki media seperti yang diterapkan di sekolah, jadi saya mengajarkan anak saya dengan cara mengenalkan huruf yang sederhana sehingga anak saya mudah bosan dan tidak semangat saat belajar. [CW $02 \mathrm{P} 3]$.

Berdasarkan kemampuan membaca yang telah diteliti dari indikator tersebut diketahui bahwa penggunaan media flashcard bisa mengembangkan kemampuan membaca anak usia 5 tahun dengan menggunakan metode berceritayang meliputi hafalan huruf abjad, menyebutkan benda-benda di setiap huruf abjad, dan membaca huruf dan gambar dengan jelas. Dibandingkan sebelum menggunakan media flashcard. Sesuai dengan pendapat Maryanto, dkk (2017) yang menjelaskan bahwa penggunaan media flashcard dapat meningkatkan pengenalan bentuk huruf siswa kelas 1 pada mata pelajaran Bahasa Indonesia di sekolah ABC Manado. Dan Rahayu (2018) yang menuliskan bahwa pengembangan media flashcard didesain dengan memperhatikan karakteristik dan kebutuhan siswa kelas III, sehingga dalam pembuatan media didesain dalam bentuk 3 dimensi dengan ukuran, bentuk, dan warna yang menarik. Efektifitas media flashcard dapat diliat dari ketuntasan hasil belajar siswa secara klasikal setelah menggunakan media yang dikembangkan mencapai $75 \%$ dan berdasarkan hasil respon guru mencapai $100 \%$ dengan sanagt baik dan respon siswa mencapai $86.25 \%$ dengan kriteria sangat baik.

Windura (2010) juga menyatakan bahwa media flashcard atau kartu kilas adalah kartu yang digunakan untuk mengingat dan mengkaji ulang dalam proses belajar. Kelebihan media flashcard yang dijelaskan oleh Indriana (2011) serta Susilana dan Riyana (2009) yang pertama adalah mudah dibawa kemana-mana karena ukurannya yang tidak besar dan ringan. Kedua adalah praktis dalam membuat dan menggunakanya, sehingga kapan pun anak didik bisa belajar denganbaik menggunakan media ini. Ketiga, media flashcard juga gampang 
diingat karena kartu ini bergambar dan sangat menarik perhatian, memuat huruf atau angka yang simpel, sehingga merangsang otak untuk lebih lama mengingat pesan yang ada. Media ini sangat menyenangkan untuk digunakan sebagai media pembelajaran, bahkan dapat digunakan dalam bentuk permainan.

\section{SIMPULAN DAN SARAN}

Berdasarkan hasil penelitian yang telah dilakukan bahwa penggunaan media flashcard ini bisa mengembangkan kemampuan membaca anak usia 5 tahun dengan menggunakan metode bercerita di TK AzZahra Klumprik Surabaya. Media flashcard yang disertai huruf abjad A-Z dan warnawarna yang mencolok juga gambar-gambar yang sangat menarik membuat anak tertarik untuk menggunakan flashcard. Oleh karena itu, penggunaan kartu flash sebagai media pembelajaran membantu anak-anak dalam mengembangkan banyak aspek perkembangan mereka, termasuk bahasa, serta merangsang kognitif (proses berpikir) dan keterampilan motorik halus.

Berdasarkan dari faktor penghambat dari guru yaitu perlu waktu yang lama karena pembelajaran saat ini secara daring dan bagi guru baru pertama kalinya menggunakan media tersebut. Kedua karena terhalang oleh jaringan sinyal sehingga terkadang membuat kurang maksimal dalam melakukan pembelajaran dengan cara menggunakan video call.

Untuk wali murid, faktor penghambatnya tidak mempunyai media seperti yang guru praktekkan kepada anaknya untuk menarik semangat belajar, jadi minat anak belajar di rumah dengan orangtua kurang maksimal dan kendalanya juga dari sinyal dan kouta.

Berdasarkan kesimpulan di atas, maka peneliti dapat memberikan saran sebagai berikut: pertama, bagi peneliti, diharapkan penelitian lebih lanjut mengenai media flashcard ini untuk dijadikan acuan pembelajaraan yang efektif dalam menunjang setiap aspek perkembangan anak. Kedua, bagi guru, diharapkan dapat memberikan pembelajaran yang lebih efektif dan bervariasi agar anak mudah memahami huruf abjad A-Z saat mengikuti setiap kegiatan yang akan dilaksanakan. Ketiga, bagi sekolah, dari hasil penelitian ini diharapkan dapat memberikan masukan yang positif mengenai media flashcard pada kemampuan membaca anak.

\section{DAFTAR ACUAN/ PUSTAKA}

Anam, S. (2007). Taman yang paling indah. Solo: Wangsa Jatra Lestari.

Anonim. (2008). Pengembangan ketrampilan bahasa anak usia pra sekolah. Jakarta: Depdiknas.

Augusta. (2012). Pengertian anak usia dini. [online]. http://infoini.com/pengertian-anakusia-dini. Diakses, 15 Agustus 2021

Bachtiar, B. (2005). Pengembangan kegiatan bercerita di taman kanak-kanak, teknik dan prosesnya. Jakarta: Departemen Pendidikan Nasional.

Dhieni, N., Dkk. (2011). Metode pengembangan bahasa. Jakarta: Univertitas Terbuka.

Djamarah, S.B. (2011). Psikologi belajar. Jakarta: Rineka Cipta.

Dryden, G. \& Vos, J. (2001). Revolusi cara belajar the learning revolution. Bandung: Mizan Media Utama,

Hartono, A., \& Sunarto (2013). Perkembangan peserta didik. Jakarta: PT. Rineka Cipta.

Indriana, D. (2011). Ragam alat bantu media pengajaran. Yogjakarta: DIVA Press

Makrifah, S.N. (2014). Penggunaan media flashcard untuk meningkatkan hasil belajar siswa pada pembelajaran ips di sekolah dasar. (Abstrak). Jurnal PGSD, 2(3).

Maryanto, R.I.P. \& Chrismastianto, I.A.W. (2017). Penggunaan media flashcard untuk meningkatkan pengenalan bentuk huruf siswa kelas 1 pada mata pelajaran Bahasa Indonesia di sekolah ABC Manado. Pedagogia: Jurnal Ilmu Pendidikan, 16(3), 305-313.

DOI: $\underline{10.17509 / \text { pdgia.v16i3.12073 }}$

Miles, B. M., \& Hubberman, M. (1992). Analisis data kualitatif buku sumber tentang metode-metode baru. Jakarta: UIP.

Rahayu, N.S. (2018). Artikel pengembangan media flashcard plus berbasis Know Want To Know Learned (KWL) Untuk Meningkatkan Keterampilan Membaca Intensif Pada Pembelajaran Bahasa Indonesia Siswa Kelas III SDN Kencong. Jurnal Simki Pedagogia, 2(3). 
Septi Ratna Sari. (2017). Penerapan metode bercerita terhadap perkembangan sosial emosional anak di PAUD Sekar Wangi Kedaton Bandar Lampung. Jakarta: Rineka Cipta.

Siti, A., dkk (2010). Perkembangan konsep dasar pengembangan anak usia dini. Jakarta: Universitas Terbuka.

Susilana, R., \& Riyana, C. (2009). Media Pembelajaran. Bandung: CV. Wahana Prima.

Sugiarsih, S. (2021). Artikel berbicara pendekatan pengalaman berbahasa. (Https://Staff.Uny.Ac.Id/Sites/Default/Files/ Penelitian/Septia_sugiarsi h, S.Pd. ArtikelBerbicara-Pendekatan-Pengalaman-
Berbahasa. Diakses 29 November 2021 jam 02:45 WIB).

Sugiyono. (2017). Metode penelitian kuantitatif, kualitatif, dan $R \& D$. Bandung: Alfabeta

Sunarto dan Hartono. (2013). Perkembangan peserta didik. Jakarta: Depdikbud.

Wati, P.R. (2021). Pengaruh media flashcard terhadap penguasaan pembelajaran $\mathrm{Al}$ qur'an hadits siswa kelas I MI Brawijaya I Trowulan. Proceedings. The Annual Conference on Islamic Education. 5(1), 256-265.

Windura, S. (2010). Mind map langkah demi langkah. Jakarta: PT. Elex Media Kompetindo. 